\title{
Constructing Haustorium-Specific cDNA Libraries from Rust Fungi
}

\author{
Ann-Maree Catanzariti, Rohit Mago, Jeff Ellis, and Peter Dodds
}

\begin{abstract}
The haustorium is a distinguishing feature of biotrophic plant pathogens. Several highly diverged pathogen classes have independently evolved haustoria, suggesting that they represent an effective adaptation for growing within living plant tissue. Despite their clear importance in biotrophy, they have been difficult to study due to the close association of biotrophic pathogens with their host and the inability to produce haustoria in vitro. These drawbacks have been circumvented in the study of rust fungi by the development of a haustoria isolation technique. The strong binding of the lectin concanavalin $\mathrm{A}(\mathrm{ConA})$ to rust haustoria allows these structures to be purified from infected plant tissue by affinity chromatography on a ConA-Sepharose macrobead column. The isolation process results in substantial yields of intact haustoria that retain their cytoplasmic contents, making them amenable to experimentation. The construction of cDNA libraries from isolated rust haustoria and their subsequent sequence analysis have provided significant insight into haustoria function at a molecular level, revealing important roles in nutrient acquisition and the delivery of pathogenicity effector proteins. The generation of a rust haustorium-specific cDNA library is described in this chapter.
\end{abstract}

Key words: Haustoria, Rust fungi, Obligate plant pathogens, Flax rust, Wheat stem rust

\section{Introduction}

The haustorium, which is produced only during infection of the host plant, is a distinguishing feature of biotrophic fungal plant pathogens. This specialised structure is formed after the host cell wall is breached, and expands within the plant cell while invaginating the host plasma membrane, and thus remains outside the host cytoplasm creating a unique host-pathogen interface. The ultrastructure of this interface has been extensively examined and consists of distinct regions showing significant differentiation (1). These include the haustorial neck which spans the host cell wall, 
and the haustorial body, which is encased by the extrahaustorial membrane derived from the invaginated host plasma membrane, and between the haustoria and this membrane, a region known as the extrahaustorial matrix (2).

Haustorial cells provide the closest contact between the fungus and the host and are therefore a likely site for molecular signalling, particularly for the establishment and maintenance of biotrophy $(3,4)$. However, early research in the molecular basis of biotrophy and gene-for-gene recognition was constrained by the growth of haustoria within host tissue making them relatively inaccessible to experimentation, and the inability to produce these structures in vitro. Although there is one account of rust haustoria forming in the absence of a living cell, they appeared immature and not completely differentiated, indicating that additional plant signals or nutrients are required to complete haustorial development $(5,6)$. The ability to isolate fully developed haustorial cells from infected host tissue has been a major factor in allowing molecular, genetic, and biochemical studies of the host-fungus interaction in a way that was not previously achievable in planta or in vitro. Recent results stemming from this technique have identified amino acid and sugar transporters in the haustorial membrane, and thus confirmed the role of haustoria in nutrient uptake (7-9). It has also now been shown that rust fungi deliver pathogenicity effector proteins into host cells from their haustoria, and these include avirulence proteins that are recognised by host-resistance proteins (10-12).

A robust haustorial isolation method was developed by Hahn and Mendgen (13), and involves affinity chromatography with the lectin concanavalin A (ConA). This method has proven to be very successful in isolating high yields of haustoria from various rust species (order Pucciniales), including broad bean rust (Uroymces fabae), cowpea rust (Uroymces vignae), wheat leaf rust (Puccinia triticina), and maize rust (Puccinia sorghi), and has subsequently been used to isolate haustoria from flax rust (Melampsora lini) $(12,14)$ and wheat stem rust (Puccinia graminis f. sp. tritici; Rohit Mago unpublished data). Electron microscopy showed isolated rust haustoria retain their cytoplasmic contents due to a blockage of the neck space by electron dense material, but lose the extrahaustorial membrane, while the extrahaustorial matrix is only partly removed (13). ConA-affinity for rust haustoria is thought to be due the presence of surfaceexposed $\alpha$-linked D-mannose within the haustorial cell wall and haustorial matrix. However, a non-specific component also contributes to binding as haustoria cannot be released from a ConA column by elution with methyl $\alpha$-D-mannopyranoside (13).

ConA-affinity chromatography has not been successful for the isolation of haustoria from powdery mildew fungi including Sphaerotheca fuliginea, Erysiphe pisi, and E.graminis f. sp. hordei, 
due to their weak binding to the ConA lectin (13). However, haustoria from this class of fungi have been successfully isolated by density gradient centrifugation (15-17). In this case, the haustoria are isolated as whole haustorial complexes, enclosed by the extrahaustorial membrane, and thus the differences between mildews and rust haustoria in their affinity for ConA may be due to differences in exposed carbohydrates.

This chapter describes the isolation of haustoria by ConAaffinity chromatography that has proved successful in our studies on flax and wheat stem rust for the generation of haustoriumspecific cDNA libraries.

\section{Materials}

\subsection{Coupling ConA to Cyanogen Bromide- Activated Sepharose Macrobeads}

\subsection{Haustoria Isolation}

1. One litre vacuum flask with sintered glass funnel $(4 \mathrm{~cm}$ diameter).

2. Whatman filter paper, Grade No. 1, (4.25 cm diameter).

3. Rotary wheel.

4. Cyanogen bromide (CNBr)-activated Sepharose 6MB (see Note 1) (GE Healthcare, cat \# 17-0820-01).

5. $1 \mathrm{mM} \mathrm{HCl}$.

6. ConA (Amersham Biosciences) dissolved in coupling buffer just before use.

7. Coupling buffer: $0.1 \mathrm{M} \mathrm{NaHCO}_{3}, 0.5 \mathrm{M} \mathrm{NaCl}, \mathrm{pH} 8.3$.

8. Blocking buffer: coupling buffer containing $0.5 \mathrm{M}$ glycine.

9. Acid wash buffer: $0.5 \mathrm{M} \mathrm{NaCl}, 0.1 \mathrm{M}$ sodium acetate $\mathrm{pH} 4$.

10. Alkaline wash buffer: $0.5 \mathrm{M} \mathrm{NaCl}, 0.1 \mathrm{M}$ Tris- $\mathrm{HCl} \mathrm{pH} 8$.

11. Storage buffer: $0.15 \mathrm{M} \mathrm{NaCl}, 10 \mathrm{mM}$ Tris- $\mathrm{HCl} \mathrm{pH} 7.2$, $1 \mathrm{mM} \mathrm{CaCl}_{2}, 1 \mathrm{mM} \mathrm{MnCl}, 0.02 \%$ (w/v) $\mathrm{NaN}_{3}$.

1. Infected plant material (see Note 2).

2. Glass Econo-Columns, $1.5 \times 10 \mathrm{~cm}, 18 \mathrm{ml}$ (Bio-Rad).

3. Waring blender.

4. Homogenisation buffer: $0.3 \mathrm{M}$ sorbitol, $20 \mathrm{mM}$ MOPS $\mathrm{pH} 7.2,0.1 \%(\mathrm{w} / \mathrm{v})$ BSA, 0.2\% (w/v) PEG 6000, 0.2\% (v/v) $\beta$ mercaptoethanol (added fresh): chilled to $4^{\circ} \mathrm{C}$ before use.

5. Two nylon meshes, one with a pore size of $100 \mu \mathrm{m}$, and the other with 20,15 , or $11 \mu \mathrm{m}$.

6. Suspension buffer: $0.3 \mathrm{M}$ sorbitol, $10 \mathrm{mM}$ MOPS pH 7.2, $0.2 \% \mathrm{BSA}, 1 \mathrm{mM} \mathrm{KCl}, 1 \mathrm{mM} \mathrm{MgCl}_{2}, 1 \mathrm{mM} \mathrm{CaCl}$. 
2.3. Generation

of Haustorium-

Specific cDNA Library
1. RNeasy Plant mini kit (QIAGEN).

2. PolyATract mRNA isolation system (Promega) or equivalent.

3. SMART cDNA library kit (BD Biosciences) or equivalent.

4. Lambda packaging extract (Epicentre Biotechnologies).

\section{Methods}

3.1. Coupling ConA to CNBr-Activated Sepharose Macrobeads
3.2. Isolation

of Haustoria

from Infected Tissue
The amount of ConA-Sepharose required will depend on the amount of tissue to be processed. As a guide, aim to make at least $15-20 \mathrm{ml}$, keeping in mind that small amounts of Sepharose are lost during the coupling and bead regeneration process. All washes described below are carried out using a funnel with a sintered glass filter under vacuum filtration. Placing a circular filter paper on top of the glass filter will assist with flow speed and the transfer of beads between steps.

1. Suspend the $\mathrm{CNBr}$-activated Sepharose $6 \mathrm{MB}$ in $1 \mathrm{mM} \mathrm{HCl}$. The gel will swell immediately ( $1 \mathrm{~g}$ equals about $3.5 \mathrm{ml}$ of swollen gel; see Note 3 ) and should then be washed with l $\mathrm{mM} \mathrm{HCl}$, using about $200 \mathrm{ml} / \mathrm{g}$ of the freeze-dried powder.

2. Dissolve ConA (5-10 mg/ml of swollen gel) in coupling buffer (use $5 \mathrm{ml}$ per gram of $\mathrm{CNBr}$ sepharose powder). Add the swollen Sepharose and mix end-over-end on a rotary wheel for $2 \mathrm{~h}$ at room temperature (see Note 4 ).

3. After incubation, wash the gel once with coupling buffer $(\sim 400 \mathrm{ml})$ to remove any excess ligand.

4. Block any remaining active groups by adding blocking buffer $(\sim 40 \mathrm{ml})$ and mix end-over-end for $2 \mathrm{~h}$ at room temperature.

5. Wash the ConA-Sepharose with three cycles of alternating $\mathrm{pH}$. Use the acid wash buffer followed by the alkaline wash buffer for each cycle, with $\sim 10 \mathrm{ml}$ of buffer per $\mathrm{ml}$ of gel for each wash. Resuspend the beads in the wash buffer briefly and then remove the buffer by vacuum filtration.

6. Equilibrate the ConA-Sepharose with storage buffer so that the volume above the gel is equal to the gel bed volume and store at $4^{\circ} \mathrm{C}$.

Several steps will require empirical adjustments according to the fungal pathogen being used, in particular the timing of tissue collection (see Note 2), the amount of infected tissue required (see Note 5 ) and the pore size of the nylon mesh used to filter the homogenised tissue (see Note 6). After weighing 
the infected tissue, all subsequent steps should be carried out at $4^{\circ} \mathrm{C}$.

1. Harvest $30 \mathrm{~g}$ of heavily infected tissue before sporulation; 5-10 days post-inoculation, depending on the advancement of the infection (see Note 2).

2. Using a Waring blender, homogenise the infected plant material in $180 \mathrm{ml}$ cold homogenisation buffer at maximum speed for $30 \mathrm{~s}$.

3. Filter the homogenate through a $100-\mu \mathrm{m}$ nylon mesh by gravity flow to remove larger cell debris, and then through a 20-, 15-, or 11- $\mu$ m nylon mesh (see Note 6).

4. Centrifuge the filtrate at $6,900 \times g$ for $5 \mathrm{~min}$ and resuspend the pellet in $6 \mathrm{ml}$ of suspension buffer.

5. Add a 5-ml bed volume of ConA-Sepharose to three columns (see Note 7) and equilibrate with suspension buffer.

6. Load $1 \mathrm{ml}$ of the resuspended pellet onto each column. Allow the suspension to migrate into the gel, then incubate for 15 min without flow, and then repeat with the remaining suspension.

7. Wash each column by carefully layering $10-15 \mathrm{ml}$ of suspension buffer on top of the ConA-Sepharose, taking care not to disturb the gel, and then allow the buffer to flow through until it runs clear (it will initially be green due to the chloroplasts washing off the column).

8. Release the bound haustoria by adding $5 \mathrm{ml}$ of suspension buffer to the column and agitating the beads by pipetting up and down using a wide bore pipette; a l-ml pipette tip with the end (2-3 mm) cut off works well.

9. Immediately after the beads settle, collect the supernatant containing the haustoria on top of the beads.

10. Repeat steps 8 and 9 and pool the eluted haustoria samples.

11. Centrifuge the suspension at $14,700 \times g$ for $5 \mathrm{~min}$. Resuspend in $1 \mathrm{ml}$ of suspension buffer and transfer to a microcentrifuge tube, retain an aliquot for microscopic analysis. The haustoria can be seen as intact structures among chloroplasts and some hyphal fragments (see Note 8). Figure 1 shows isolated flax rust haustoria.

12. Re-pellet the haustorial suspension, remove the supernatant, and weigh sample before freezing in liquid nitrogen, then store at $-80^{\circ} \mathrm{C}$ until RNA extraction.

3.3. Regeneration of Column
To regenerate the ConA-Sepharose beads, remove from the column (see Note 9) and wash as given in step 5 of Subheading 3.1. The gel can then be equilibrated with storage buffer and stored at $4^{\circ} \mathrm{C}$. 

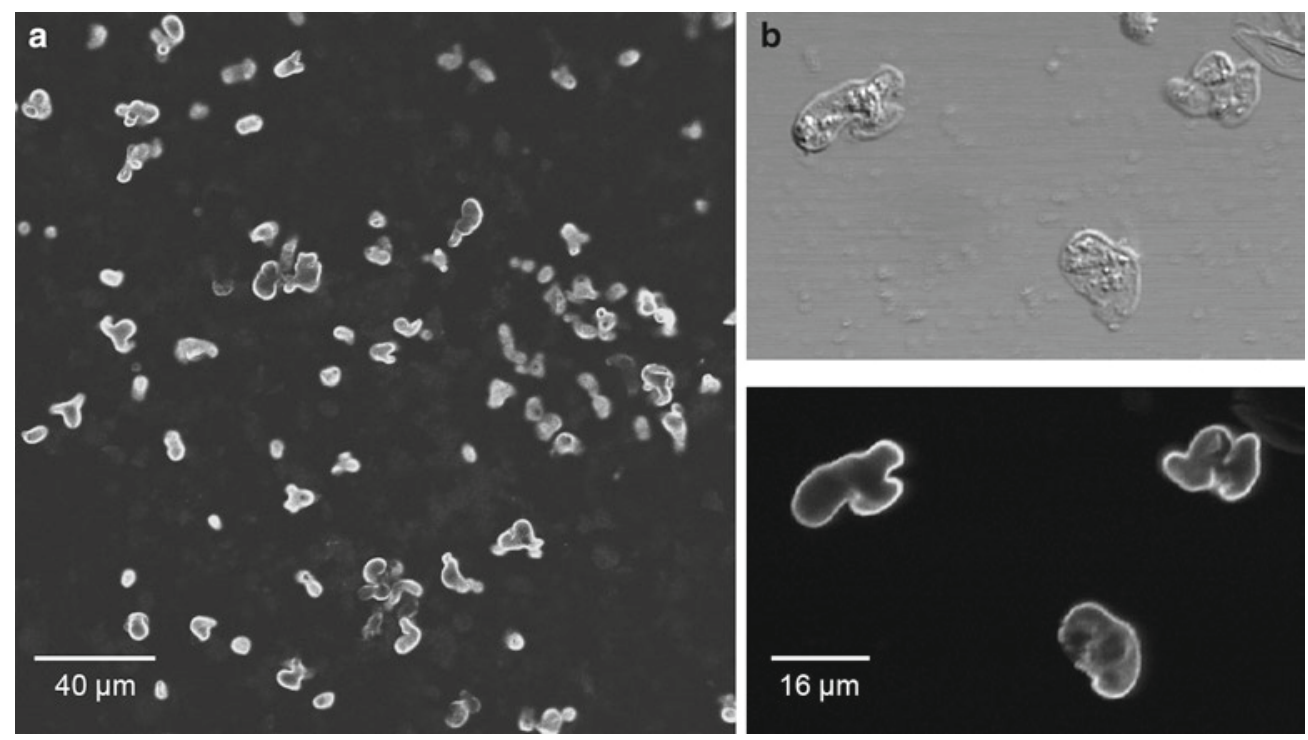

Fig. 1. Isolated flax rust haustoria labelled with monoclonal antibody ML1, which specifically binds to a surface carbohydrate epitope present in the haustorial cell wall of Melampsora lini (14). Images were collected on a Leica TCS SP2 confocal microscopy. (a) Fluorescence image showing immunolabelled haustoria in green. (b) Higher magnification showing haustoria as intact structures under bright-field (top) and fluorescence (bottom).

\subsection{Generation of Haustorium- Specific cDNA Library}

3.4.1. Isolation of $M R N A$

3.4.2. Generation of $c D N A$ Library
1. Isolate total RNA from frozen haustoria samples using the RNeasy Plant Mini Kit from QIAGEN, following the protocol for "plant cells and tissues and filamentous fungi."

2. Grind the frozen haustoria sample (no more than $100 \mathrm{mg}$ per column; $30 \mathrm{~g}$ of infected flax tissue will give a haustorial pellet of approximately $80 \mathrm{mg}$ ) thoroughly with a mortar and pestle in liquid nitrogen.

3. Add the ground powder to $450 \mu \mathrm{l}$ of Buffer RLT and proceed with the manufacturer's protocol.

4. The RNA yield can be increased by using two aliquots of RNase-free water when eluting from the column. All processed samples can then be pooled and the volume reduced to $\sim 100 \mu \mathrm{l}$ in a vacuum centrifuge.

5. Optional (see Note 10): treat the RNA with DNase and cleanup the reaction using the "RNA cleanup and concentration" protocol. As a guide, $30 \mathrm{~g}$ of infected flax leaf tissue will yield $\sim 5 \mu \mathrm{g}$ of total RNA, and similar yields were obtained for stem rust.

6. From the total RNA, isolate mRNA using polyATract mRNA isolation kit (Promega).

1. Using $0.025-0.5 \mu \mathrm{g}$ of haustorial mRNA (see Note 10), generate cDNA with the SMART cDNA Library kit (BD 
Biosciences) following the cDNA synthesis by long distance (LD) PCR protocol.

2. Package the library into lambda phage using the MaxPlax lambda packaging extract (Epicentre Biotechnologies), then titrate and amplify following the SMART cDNA library kit protocol.

Lambda clones can be converted to plasmids in Escherichia coli strain BM25.8 using the protocol given in the SMART cDNA library kit manual. Colonies can be picked using blue/ white selection on $\mathrm{X}-\mathrm{Gal}$ plates and grown overnight in 96- or 384-well microtiter plates. Cultures can then be used directly for PCR and subsequent sequencing to characterise the insert, and then frozen as glycerol stocks.

\section{Notes}

1. It is important to use $6 \mathrm{MB}$ beads which are designed specifically for cell affinity chromatography and have a large bead size $(250-350 \mu \mathrm{m})$ to allow minimal trapping of non-specific cells when passing mixed cell suspensions through the column.

2. Harvest tissue as late as possible to increase the number of haustoria, but should be at least 1 day before pustule eruption; 5-6 days for flax rust, 8-10 days for stem rust (for the latter, collection should be as soon as the first signs of infection are visible, i.e. the appearance of yellowing spots).

3. Significantly less swelling of the freeze-dried powder (than the stated $1 \mathrm{~g}$ to $3.5 \mathrm{ml}$ ) is an indication that the Sepharose macrobeads have expired and should not be used.

4. The ConA coupling step can also be performed overnight at $4^{\circ} \mathrm{C}$, and while other gentle mixing methods can be employed, do not use magnetic stirring as this will damage the beads.

5. For flax rust, RNA yields were $\sim 5 \mu \mathrm{g}$ of total RNA from $30 \mathrm{~g}$ of infected plant material. Thus multiple isolations were required to generate sufficient material for library construction. For stem rust, we obtained similar RNA yields but scaled up each isolation to $\sim 80 \mathrm{~g}$ of infected material.

6. The size exclusion provided by the mesh pore size is an important step for pure yields of haustoria as large numbers of contaminating cell types can become trapped within the column of Sepharose beads (note, the Bio-Rad Econocolumns have a $28-\mu \mathrm{m}$ sintered filter). Rust fungi display a 
diverse range of haustorial size and morphology, so to choose the pore size of the second nylon mesh, perform a small-scale isolation and microscopic analysis with each of the three nylon meshes to determine which is optimal for purity and yield. Alternatively, collect haustoria using the $20-\mu \mathrm{m}$ mesh and measure the size of haustoria and any intact plant cell sizes that are present by microscopy using an eyepiece graticule. As an example, isolation of flax rust haustoria using the $20-\mu \mathrm{m}$ mesh will give a higher yield of haustorial cells than the $11-\mu \mathrm{m}$ mesh (number of haustoria per $30 \mathrm{~g}$ tissue: $2.9 \times 10^{6}$ versus $\left.4.5 \times 10^{5}\right)$, but the $11-\mu \mathrm{m}$ mesh is required to exclude intact plant cells and thus will result in the greatest purity (purity as the percentage of haustorial cells among total number of intact cells: $49 \%$ versus >99\%). For P. graminis haustoria $15-\mu \mathrm{m}$ mesh was used. In this case no plant cell contamination was observed with the $20-\mu \mathrm{m}$ mesh, but some rust spores were not excluded by this mesh size.

7. The use of three columns each containing a $5-\mathrm{ml}$ bed volume of ConA-Sepharose, rather than one containing $15 \mathrm{ml}$, is more convenient during the elution of the bound haustoria due to the bead agitation that is required. Using two columns of $7.5 \mathrm{ml}$ was also found to be relatively convenient.

8. Retain an aliquot of the eluted haustoria for microscopic examination to determine the integrity of the haustorial cells and the purity of the sample. The number of isolated haustoria can be calculated using a hemocytometer (see Note 5 above). Other cell types observed within the haustoria suspension include some hyphal fragments, which unlike the isolated haustoria have sheared ends and are devoid of cellular contents, and chloroplasts. However, the contribution of total RNA from contaminating chloroplasts was investigated and found to be relatively insignificant (18).

9. The column can be used several times before needing regenerating. To remove the gel from the column, add elution buffer and invert several times, then pour out into the funnel, with sintered glass filter and filter paper, for washing with $\mathrm{pH}$ buffers.

10. Although it is stated that a cDNA library can be constructed using total RNA with this kit, we highly recommend the use of mRNA as we observed non-specific priming of the modified oligo(dT) primer (CDS III/3' PCR Primer) on ribosomal RNA or contaminating DNA during first-strand synthesis. If using total RNA for library construction, a DNase treatment is also recommended after RNA isolation. 


\section{References}

1. Harder, D. E. (1989) Rust haustoria - past, present, future. Can. J. Plant Pathol. 11, 91-99.

2. Voegele, R. T. and Mendgen, K. (2003) Rust haustoria: nutrient uptake and beyond. New Phytol. 159, 93-100.

3. Heath, M. C. (1997) Signalling between pathogenic rust fungi and resistant or susceptible host plants. Ann. Bot. 80, 713-720.

4. Panstruga, R. (2003) Establishing compatibility between plants and obligate biotrophic pathogens. Curr. Opin. Plant Biol. 6, 320-326.

5. Heath, M. C. (1989) In vitro formation of haustoria of the cowpea rust fungus, Uromyces vignae, in the absence of a living plant cell. I. Light microscopy. Physiol. Mol. Plant Pathol. 35, 357-366.

6. Heath, M. C. (1990) In vitro formation of haustoria of the cowpea rust fungus Uromyces vignae in the absence of a living plant cell. II. Electron microscopy. Can. J. Bot. 68, 278-287.

7. Voegele, R. T., Struck, C., Hahn, M. and Mendgen, K. (2001) The role of haustoria in sugar supply during infection of broad bean by the rust fungus Uromyces fabae. Proc. Natl Acad. Sci. U. S. A. 98, 8133-8138.

8. Struck, C., Ernst, M. and Hahn, M. (2002) Characterization of a developmentally regulated amino acid transporter (AATlp) of the rust fungus Uromyces fabae. Mol. Plant Pathol. $3,23-30$.

9. Struck, C., Mueller, E., Martin, H. and Lohaus, G. (2004) The Uroymces fabae UfAAT3 gene encodes a general amino acid permease that prefers uptake of in planta scare amino acids. Mol. Plant Pathol. 5, 183-189.

10. Dodds, P. N., Lawrence, G. J., Catanzariti, A., Ayliffe, M. A. and Ellis, J. G. (2004) The Melampsora lini AvrL567 avirulence genes are expressed in haustoria and their products are recognized inside plant cells. Plant Cell 16, 755-768.

11. Kemen, E., Kemen, A. C., Rafiqi, M., Hempel, U., Mendgen, K., Hahn, M. and Voegele, R. T. (2005) Identification of a protein from rust fungi transferred from haustoria into infected plant cells. Mol. Plant Microbe Interact. 18, 1130-1139.

12. Catanzariti, A., Dodds, P. N., Lawrence, G. J., Ayliffe, M. A. and Ellis, J. G. (2006) Haustorially expressed secreted proteins from flax rust are highly enriched for avirulence elicitors. Plant Cell 18, 243-256.

13. Hahn, M. and Mendgen, K. (1992) Isolation by ConA binding of haustoria from different rust fungi and comparison of their surface qualities. Protoplasma 170, 95-103.

14. Murdoch, L. J., Kobayashi, I. and Hardham, A. R. (1998) Production and characterisation of monoclonal antibodies to cell wall components of the flax rust fungus. Eur. J. Plant Pathol. 104, 331-346.

15. Dekhuijzen, H. M. (1966) The isolation of haustoria from cucumber leaves infected with powdery mildew. Neth. J. Plant Pathol. 72, $1-11$.

16. Gil, F. and Gay, J. L. (1977) Ultrastructural and physiological properties of the host interfacial components of haustoria of Erysiphe pisi in vivo and in vitro. Physiol. Plant Pathol. 10, $1-12$.

17. Manners, J. M. and Gay, J. L. (1977) The morphology of haustorial complexes isolated from apple, barley, beet and vine. Physiol. Plant Pathol. 11, 261-266.

18. Hahn, M. and Mendgen, K. (1997) Characterization of in planta-induced rust genes isolated from a haustorium-specific cDNA library. Mol. Plant Microbe Interact. 10, 427-437. 